Narotzky, S. (2016) “On Waging the Ideological War: Against the Hegemony of Form” Anthropological Theory, Vol. 16(2-3): 263-284

Author: Susana Narotzky, Universitat de Barcelona

Contact details: Narotzky@ub.edu

Title: On waging the ideological war: against the hegemony of form

Abstract: This article seeks to rehabilitate the concept of ideology as a necessary tool of struggle against present-day capitalism. Post-structuralist epistemologies, by celebrating pluralism and the emergent character of knowledge and politics, have rendered the intellectual production of a unitary theory an obsolete remnant of a Modernist past. I contend that these well meaning anti-authoritarian epistemologies unwillingly express the hegemony of a form that the Austrian school proposed for market competition in the first half of the $20^{\text {th }}$ century. Based on ethnographic material of Spain I acknowledge the need to develop a new conceptual framework that captures the singular experienced realities of the present but links them in a coherent unitary theoretical structure. The productive power of the "hegemony of form" requires the construction of an ideology that may not only destroy it, but also provide the basis of a counter-hegemony for producing a better future.

Keywords: Ideology, Hegemony, Austrian school, Post-structuralist epistemologies, Solidarity, Social mobilization 


\section{On waging the ideological war: against the hegemony of form}

“C’est cette démultiplication de la forme ‘entreprise’ à l’intérieur du corps social qui constitue, je crois, l’enjeu de la politique néolibérale. Il s’agit de faire du marché, de la concurrence, et par conséquent de l’entreprise, ce qu’on pourrait appeler la puissance informante de la société.” p.154 ... “Il s’agit (...) d’obtenir une société indexée non pas sur la marchandise et sur l’uniformité de la marchandise, mais sur la multiplicité et la différenciation des entreprises.” p.155

Foucault 2004 [1979] Naissance de la biopolitique, emphasis added.

\section{Introduction}

What is the power of ideology? ${ }^{1}$ How do intellectual constructs become frameworks through which people make sense of the field in which they may act? Can ideology be materially inscribed in experience? The importance of the performative force of abstract economic models and technical devices (in particular those that sustain various capitalist processes) has been increasingly highlighted (Holmes, 2009; Miyazaki, 2006). Moreover, scholars have stressed that the power to discipline and constrain livelihood options is linked to the forceful expansion and institutionalization of particular knowledge constructs (De Angelis, 2007; Perelman 2000). Often this analysis has gone hand in hand with a critique of 
modern epistemology and its separation of reality and representation, object and subject, pointing to the co-development of categories in which distancing and differentiation constitute emergent power fields in the process (Mitchell, 2002).

The point I am interested in is different, however. I want to explore the ground for creating possible counter-movements. That is, what kinds of instruments, intellectual models, social innovations and other devices are needed to change the present situation into one that makes people's lives better? The moral element here is problematic as it is at once unavoidable and questionable, for morality is always tied to a particular idea of the good (the good life, the common good), and this in turn results from the general models of the world (emergent and instituted cosmogonies), the interactions among its constitutive elements (also emergent categories tied to epistemologies), and the power of agents (human subjects, assemblages, actants, etc.) to make them seemingly attuned to real life experience (hegemony). In staking my position within this problematic and contested terrain I offer this article as a very preliminary proposition that seeks to rehabilitate the concept of ideology as a necessary tool of struggle against present-day capitalism. I set my thoughts on the paper as an exercise in clarifying my own ideas, with the hope that this will contribute to the pressing, wider tasks of theory that confront all those engaged in struggles for social and economic justice.

\section{The withering of ideology as a useful concept}

In this paper I generally speak of hegemony when referring to the “dominant ideology" that serves the social reproduction of the present-day capitalist system. By critically 
addressing the Austrian school's economic model, which rests on an apparently a-political methodology for the elicitation of knowledge, I wish to show the powerful hegemony of this formal procedure that has become inscribed in everyday practice. I speak of ideology mostly in relation to what has been defined as "oppositional ideology”, a framework emerging from and enabling struggle. Following Eagleton (1991) I make a distinction between the ontological, the epistemological and the political aspects of ideology. The ontological aspect refers to the illusion of reality that an ideology may provide: something that appears to exist and does not. The epistemological aspect refers to the truth or falsehood between reality and its conscious practical and theoretical understanding. The political aspect is a function of struggle, of the intellectual resources that can be produced to support the interests of a group or class which are engaged in an actual (structural) confrontation. The epistemological and political aspects are the ones relevant for the purpose of this paper. The three aspects are difficult to disentangle and often collapse into each other in many definitions and I will not develop this further.

Gramsci speaks of “economism” as a hegemony which produces an understanding of reality that is methodologically wrong: the separation of economy-civil society from Statepolitical society (Gramsci, 1987:160). He notes that trade unionism, although expressing the struggles of a subaltern interest group, was nevertheless part of the same hegemonic understanding that benefited the bourgeoisie and was embedded in laisser-faire policies. Although this “methodological” error (the separation) can remind us of the famous disembedding aspect of the economy from society described by Karl Polanyi (1971) for capitalist economies, it is different. Gramsci's intention is to show the dead-end of certain 
forms of struggle that become trapped in the spider webs of what they seek to transform. His entire development of the concept of hegemony is an attempt to show the processes through which political and economic aspects of society are bound together not in a deterministic and automatic manner, but through tactic and strategic activity. His objective was to create the conditions of possibility for a complete transformation of the political and economic system in the benefit of "the many”. For this to happen people's life experience entrenched in common sense notions of why things were as they were must be transformed into a theory, a proper philosophy of praxis that explained what that reality was and how to transform its structure in the form of an alternative, and how to achieve it. Only if that theory was able to explain reality, and the alternative emerging from it could satisfy a majority of people, would it be capable of yielding sufficient power to change things for the long-term. Hegemony was produced in the dialectical process involving practical knowledge embedded in and emerging from experience, and theoretical knowledge in conversation with other explanatory models: this was the philosophy of praxis (Gramsci, 1987: 333-4). ${ }^{2}$

But economism as a hegemony was also a particular kind of ideology, meaning an intellectual model that obscured or misrepresented reality. It was therefore an obstacle to explaining reality in a way that would express people's real experiences as well as provide a logical framework for their understanding and transformation. Hegemony, however, made this ideology not a veil that masks but an actual aspect of reality, hence its power (Gramsci, 1987:164-5). 
The line between ideology and hegemony is often fuzzy and seems to hinge on the greater or lesser capacity of those that are embedded in it (produce and reproduce it) to be conscious of its power dimension. The more conscious we are of the power effects of models that support our actions and the more we are able to consider them as constructed objects that can be analyzed, the more we can treat them as ideology and begin to challenge them. The less conscious we are of the power effects, the more the models have become part of our habitus and we lack distance to challenge them as mere intellectual objects. Reflexivity appears early on in Marxism, especially related to the need to connect with ordinary people's subjective feelings and understandings in order to effectively mobilize them (e.g. Rosa Luxemburg, 1999; Antonio Gramsci, 1987; Raymond Williams, 1989). It is also tied to the efforts to include non-proletarian forms of exploitation (such as peasant petty commodity production, bonded labour) and oppression (linked to race, gender). Still the epistemology of Marxism rests on a modernist idea of science where subject and object must be clearly distinguished in the operation of knowledge construction. ${ }^{3}$ I seek to address the power that ordinary human subjects, in concrete historical settings that provide particular instruments (material and immaterial), exercise in order to challenge and change the dispossessions they experience. Based on my research, I ask what these people do, why do they do it and how does it change their lives and expectations.

I have been involved for over 10 years with a large group of male industrial workers and their families in a town in the NW of Spain. The area has been in ongoing restructuring since the 1980s and early retirement, lay offs, and long-term unemployment have become the norm. Women have increasingly found temporary jobs in the service sector and younger 
generations are generally unemployed, have precarious jobs in contract firms or have migrated. Historically, labor struggle structured through class-based unions has been ubiquitous here, and has yielded what people voice as “conquests” (universal public services such as health and education, and political rights through parliamentary democracy). Today, the situation is one of generalized uncertainty and hesitant forms of resistance. As years have passed I have observed three distinct processes (1) the waning of a working class faith in unions and union mobilization, (2) the multiplication of forms of activism that target concrete issues, and (3) a creeping hopelessness demobilizing younger generations.

In this context, old-time unionists who have shifted their struggle toward social activism tend to analyze situations in terms of local connection with larger processes expressing structural logics. Analysis produces the design of a strategy and tactical mobilizations that they strive to explain in an endless pedagogy of struggle. Knowledge and theory become instruments of change and are understood as stemming from everyday life experience. In contrast, younger people -with the exception of a small group of young, unionized industrial workers - tend to present the local situation as an aggregate of concrete personal experiences. A few build collective supports based on social networks, a practice that they sometimes abstract as a theory of solidarity that challenges the state and capitalism by opening spaces where alternative provisioning processes put people instead of profit as the aim. Their theory is also based on their experience, on political and social mobilizations (15M, Indignados, Anti-Foreclosure Platform) and miscellaneous readings that encompass 
a wide range of perspectives including political economy, political ecology, anarchism, degrowth, social and solidarity economy, and commoning.

Both groups stress the need to be aware of and respect the multiple social positioning of those that suffer from capitalism. In practice, however, the older group tends to produce a coherent model and to design a unified oppositional strategy, while the younger group is explicitly unwilling to do so. As a result, the local practice of social activism is a succession of short-term targeted actions often subjected to the tensions of endless idiosyncratic strategies. Demoralization is recurrent and is expressed in the small numbers and high turnover of younger people in activist groups.

If we factor history in, it is difficult to describe the situation of the present younger generation as "worse" than that of their predecessors. Yes, they are massively unemployed or in precarious jobs, but "stable” industrial jobs in the 1950s and 1960s in Spain under fascism did not provide a much better livelihood. The present day welfare state and universal public services, however shrunken, are much better than the previous non-existent ones. One major difference is the lack of expectations for a brighter future on the part of the younger, better educated generations. Another major difference is their unwillingness to produce or adopt a coherent oppositional ideology that could become counter-hegemonic.

\section{The remains of an old debate: The hegemony of form}

With this in mind, I interrogate the fierce criticism and ultimate abandonment of the concept of ideology as an instrument for struggle by those who would like to change the existing structure of power and economic distribution. I suggest that (a) distrust of the 
concept's validity stems from the unbeknownst domination of a neoliberal conceptual toolkit, in particular as it has been instituted by the rise of the Austrian school and its hegemony in neoliberal though. This has resulted in (b) an incapacity to imagine an alternative project that does not ultimately rest on the basic formal premises of neoliberalism: individualism (or singularity), freedom and exchange.

The Austrian school developed as a coherent ideological model during the 1940s and 1950s (Hayek, 1948; for an account of the emergence of the Austrian school see Foucault, 2004) and became established as a powerful economic model in the 1990s (Harvey, 2007). Its major innovations emerged from the "Socialist calculation" debate that dated from the early $20^{\text {th }}$ century (Hayek, 1938; Lange, 1936, 1937). What was at stake in this apparently technical debate was an epistemological issue of import: could society exist as a coherent whole and the knowledge about it be gathered and organized to meet a particular end? Or was reality an emergent result of the interaction of "dispersed bits of incomplete and frequently contradictory knowledge which all the separate individuals possess” (Hayek, 1948:77), and hence could not be organized to advantage? Although in a first round the debate seemed to have been won by the "socialist" camp, in a second round the Austrian school imposed its views and eventually became hegemonic. The point I wish to make here is that the triumph of the epistemological premise for eliciting knowledge that the Austrian school proposed as being the only possible way to capture the reality of imperfect market competition has permeated our lives becoming an hegemony of form.

The debate hinged on how to achieve market coordination. The "socialist" side maintained the parameters of neoclassical market theory (perfect knowledge, competition, equilibrium 
and efficient allocation) but focused on the problems of calculation and planning. In contrast the Austrian school introduced the discovery of tacit knowledge as key to the model of market operation. This important shift from the neoclassical model stemmed from the awareness that real market situations were based on imperfect knowledge. ${ }^{4}$ It then assumed that competition was a creative process that elicited knowledge about possible demand. Hence, “the problem is how subjective, or tacit, knowledge, necessarily fragmented and dispersed, can be socially mobilized” (Adaman \& Devine, 1997:59). Hayek argued "that the mobilization and coordination of this incomplete and contradictory knowledge occur through the actions of entrepreneurs, competing against one another in the market process, discovering and learning what is and is not possible.” (Adaman \& Devine, 1997:59). This creative dynamic not only required entrepreneurship but also a constant effort at innovation, that is, of creating difference that would momentarily provide monopoly advantage in the market. ${ }^{5}$ In the 1980s and 1990s scholars in the West (Adaman and Devine, 1997; Elson, 1988) attempted to counter the Austrian economic school’s expanding hegemony in a context of increasing hardship of the population subject to structural adjustment programs. They revisited the parameters of the original debate about market coordination in socialism in an attempt to reconfigure them while vindicating their worth for a new socialist project. ${ }^{6}$

The Austrian school's underlying assumptions about the form of eliciting knowledge from discrete and dispersed social agents, which was the crux of that debate, are in my opinion similar to contemporary efforts to theorize an alternative to capitalism that would support a unified political struggle and durable transformation. In its central methodological 
assumption about how to elicit tacit knowledge through exchange, a process that will be then expressed in prices which will guide further action, this model contains some formal significant parallels with certain practices of present day (de)mobilizations and the critical theories that sustain them.

The basic premise of the Austrian school is the existence of dispersed (independent and autonomous) individuals possessing largely “tacit” knowledge (i.e. pre-conscious or unconscious knowledge) (M. Polanyi, 1967). It is this methodological (formal) premise which, I suggest, is enacted ${ }^{7}$ by present-day anti-capitalist and social justice mobilizations and may be at the source of their incapacity to produce a coherent and robust counterhegemony. The emergent aspect of knowledge about the world that results from free market interaction and supports the economic model appears to me similar in its form to poststructuralist epistemological and political models such as the "sociology of emergences" (Santos, 2004a) or the virtual “constituent power” of a multitude of desiring subjectivities (Negri, 2009). While this anti-authoritarian view of the world is extremely attractive to radical activism it seems to lack the capacity to become counter-hegemonic precisely because it is based on a form that is like the one that supports the system it seeks to transcend. I am not saying that this is an intentional or even conscious move, on the contrary, in my opinion it expresses the hegemony of form. Indeed, in the post-structuralist mobilization / activism theories, the political project is created through a process of permanent discovery as a result of the free interaction of subjectivities, knowledges, and world(view)s. ${ }^{8}$ The creative, innovative and democratic aspect of this emergent politics is opposed to Western ideologies and institutions of modernist liberal politics. In particular, 
this new form of politics is premised on eliciting difference as opposed to the "enlightened" aim of eliciting equality, a shift that parallels the move from neoclassical to Austrian models of the economy.

The shift is subtle but can be found in the premise that the forces of political change should arise from autonomous -equal but essentially different - entities or "singularities" (be it individuals or quasi-corporate groups such as “communities”) that, to push the metaphor further, could be described as adopting an “enterprise form” (Foucault, 2004:154) and interacting in a "market-like” arena (e.g. a "forum”) where they create social value. However, in these oppositional political models cooperation rather than competition is the relationship that produces social value in the exchange arena and this is a major difference. To use Lazaratto’s words, common goods emerge “as a result of co-creation and corealization of the cooperation of ordinary subjectivities” in the event-driven arena (Lazaratto, 2006:129). These new models eschew the old revolutionary ideologies that were premised on designing a whole (brave) new world on the basis of understanding existing relations as a connected totality that needed to be challenged in its entirety. According to Santos (2003a: 243). "There is no unique theory to guide the movements, because the aim is not so much to seize power but rather to change the many faces of power as they present themselves in the institutions and sociabilities. At this level, the novelty consists in the celebration of diversity and pluralism, experimentalism, and radical democracy.” These movements are understood as able to open up spaces where the plural visions of alternative (better) worlds can emerge and be expressed. Through their punctuated practices they 
challenge in myriad ways the hegemony of capitalism and provide content for the critical theorization of political struggle.

While these oppositional movements are undoubtedly a form of struggle, which produces results and unleashes counter-hegemonic forces, I suggest that their fragmented expression (in practice and theory) and their unwillingness to unify the struggle around an ideological project blocks their ability to overhaul our globalized society. Why is this so? My hypothesis is that the event-driven pluralistic political model while considered revolutionary by its promoters may be the paradoxical expression of a hegemonic neoliberal "power informing society", the power of form (Foucault, 2004:154). In an illuminating passage, Terry Eagleton (1991:85-86) analyzes the contribution of Marx’s commodity fetishism theory for the thinking of ideology, here understood as deceptive beliefs. In his view, commodity fetishism shifts our understanding of ideology from the discursive constructions of a particular class to the material structure of society as a whole. Collective social relations appear as relations between discrete things that exercise power over actual human relations. Hence "mystification, so to speak, is an 'objective' fact embedded in the very character of the system: there is an unavoidable structural contradiction between that system's real contents, and the phenomenal forms in which those contents proffer spontaneously to the mind.” (Eagleton, 1991:86) This insight can be usefully extended to the new forms of political struggle. The 'phenomenal forms' of struggle (discrete challenges guided by emergent fragmented knowledge) are a result of the present-day 'character of the system' but contradict 'that system's real contents' (the connectedness of capitalist processes of dispossession). 
Indeed, what strikes me as particularly relevant is the historical conjuncture of emergence of contemporary social movements and post-structural political theory in a context where the Austrian neoliberal model of the economy is hegemonic and where the transformations that it has brought about in the everyday practice of contemporary capitalism are dissolving the experience of a collective working-class agent. I turn now to the ethnography.

\section{Ethnographic intelligence: What we learn from the field}

In order to illuminate this issue further I try to pay attention to what some people who selfidentify as being "injured" by capitalism but who do not define themselves as "activist" say about what matters to them in the present conjuncture of structural adjustment. When listening to narratives of their lives in this NW corner of Spain, five aspects are recurrently highlighted, each of which points to conflicts that express their relationship with the system.

(1) The centrality of care. People talk about giving and receiving care both in its material and emotional forms. Care is not just a mutual claim that individuals address to each other; it is also a claim on the collective, the family, the community and the state (or other powerful institutions such as the Church). But this caring activity is fraught with misunderstanding and conflict. Generally the conflict stems around the understandings and tensions of dependence and autonomy that interdependent people try to negotiate.

(2) The importance of doing. People stress that they need to "work", not only because it is a way of providing an income and hence a means of livelihood, but very centrally because it makes them feel alive. Expending creative energy, whatever the difficulty and stress such 
effort entails, is better than its absence. However, work in this context is fraught with conflict because it simultaneously produces feelings of autonomy, heteronomy and dependence. These conflicting feelings about work express the need to preserve the mindbody from breaking down under the joint, albeit dissimilar forces of productivity pressures, patronage requests and solidarity claims.

(3) The capacity to have a long-term life project. Young people want to have the possibility of designing a path into their individual future including a career, getting married, raising children, and buying a home. This is a will to control their destiny and the choices they make to fulfill their desires. Their expectations should become part of a "plan" that would become a guideline to follow or a possibility towards which to aspire (Bourdieu, 2003; Narotzky and Besnier, 2014). Social projects aiming at forging a better world are framed as immediate struggles targeting concrete livelihood issues such as food and housing, and resting on an appeal to solidarity that fosters mutual help while enhancing self worth. The conflict young people experience in this domain stems from the implosion of the environment of expectations, that is, the grid of interdependent processes that they had imagined as relatively secure. Instead they face the injunction to permanently "re-invent" themselves, something they understand as a symptom of their loss of the opportunity to construct a long-term life project. They resent this entrepreneurial metaphor of the self as a heteronomous imposition although they sometimes define it as a liberating practice.

(4) The claim to recognition. People speak of "dignity", and feel deprived of it in the present even as they vindicate it as a "conquest" of the struggles of their working parents. Their parents had achieved the dignity of being considered as full-fledged citizens not only 
with nominal equal rights but also with claims to equalization processes through state redistribution. To claim dignity is to be part of something larger and beyond oneself and to have a position that is recognized as meaningful in this wider system. Recognition is a political aim that gathers its meaning from an idea of society as an existing entity, one were people as individuals hold a valued place as members of an interdependent whole. It is the means to acquire personal worth, while simultaneously creating worth for the collective. Conflict here emerges from the fact that people (in particular younger generations) are not given a meaningful space within their society and that they are pushed to feel socially redundant (Smith, 2011; Li, 2009; Ferguson, 2013).

(5) The requirement of responsibility. Like the previous claim, this one stems from the need to understand individual action as a process linked to other people's wellbeing. It is a socially grounded claim to have people (as individuals or as institutions) be responsible for their actions. There is an individual aspect as people point to concrete agents as responsible for a particular harmful deed, and there is also a claim to a wider institutional responsibility (often personified) for actions that harm the collectivity. This responsibility is voiced in either very specific terms (moral responsibility of parents to care for their children or vice versa) or in very abstract terms (failed responsibility of the system, capitalists, banks, the state, etc.) Conflict arises in the tension between being identified as responsible for particular misdeeds by others (e.g. banks pushing subprime mortgage responsibility on irresponsible client's actions or on financial illiteracy) and, simultaneously, demanding responsibility from particular or institutional others (e.g. corruption). Responsible practices are linked to the understanding that the continuity of society, the interdependent historical 
reality that is imagined as a meaningful entity (e.g. "having a life"), is based on the existence of specific instances of co-operation that are instituted through an understanding of mutual obligation.

The conflicts that emerge from these five considerations of what really matters for having a life worth living are expressed in struggles to make it happen. Sometimes the struggles take the form of individual strategies seeking the support of kinship networks, yet often they appear as organized collective mobilizations under the banner of solidarity. Mostly, however, these struggles are discrete and unconnected reactions to the attacks of structural adjustment on people's livelihood resources and expectations. If we think of ideologies as a function of struggle, as the intellectual weapons of class struggle (Eagleton, 1991:90), the inability to create a coherent ideology that would support a unified project of social transformation becomes a serious handicap.

With present deepening of structural adjustment policies in the Western centers and semiperipheries, structural unemployment expands while stable employment is replaced by temporary, precarious, often informal work. As a result the "working poor" category becomes ubiquitous and the distinction between "formal" and "informal" work is increasingly meaningless for people who go from one to the other recurrently, or hold jobs that can be described as one or the other. Moreover, the expansion of people who are nonwaged and self-employed and of micro-firms (of two or three personally acquainted “entrepreneurs" trying to put together an income generating activity) often in the grey zones of subcontracting or service provision, has completely changed the expectations of a majority of people. 
Many do not have "expectations” at all and enact a picaresque of day-to-day tactical maneuvers to make ends meet. In order to access needed resources others activate family networks or claim subsidies from the state, in each case asking that these actors take on the responsibilities of care. Yet others attempt to make good within the "entrepreneurial" model that is endorsed by the dominant discourse. As petty entrepreneurs or self-employed suppliers they confront an unfavorable credit and tax context that impairs their competitive position, and drives them to “self-exploitation”. Finally some people choose movement and migrate, in the hope of finding work abroad and a better life (Pine, 2014).

This situation has produced a welfare paradox that has reconfigured the meanings of solidarity. Indeed, while corporate welfare becomes an entrenched policy (favored by national and supra-national bodies alike), social welfare, in addition to being cut, has been demonized as creating dependency and obstructing individual initiative. But at the same time, European neoliberal states praise forms of “community” solidarity and family dependencies as being better forms of social support and responding to immediate forms of care obligation (e.g. family), that should not be transferred to the state (Collins and Mayer, 2010; Pitrou, 2003; Thelen, 2015). The family and community “safety-net” which in Europe was the Mediterranean social welfare model attributed to Southern countries (Spain, Italy, Greece, Portugal) has increasingly been defended as a convenient complement to the neoliberal rolling-back of the state for northern countries as well (e.g. Netherlands, UK) (Lowndes and Pratchett, 2012; Meyer, 2014; Jacobs and Manzi, 2013).

What theoretical frameworks do people produce to explain these experiences and guide their challenge to a system that exploits and oppresses them? To the majority, both the 
market and the state have become irresponsible in terms of providing the means for a decent livelihood. The market does not provide jobs or sufficient income to live on, and the state is rolling back and privatizing basic services such as education, health, retirement pensions and social housing while increasing the pressure of taxation on ordinary people. People are made to feel redundant socially, something that they express as a loss of dignity, and of their place in society. Their only value for the state seems to be as fiscal cash-cows to be milked through indirect taxation. Feeling useless while feeling over-taxed and under-serviced are paradoxical understandings of their social position as citizens. These are emotional expressions of being pushed away while being taken advantage of. In this predicament people look for support elsewhere and turn to personal networks of solidarity, primarily based on the immediate family or charitable, religious and mutual help associations (Muehlebach 2012). At the same time these solidarities are the only relationships that carve a new meaningful social space, although one with ambiguous interpretations and strong emotional contradictions (as when adult children with their families take refuge in their retired parent's home, becoming what one parent described as “internal refugees”).

In the social mobilizations and organized movements that have emerged since 2008, autonomy, dependency and solidarity are often used to explain the changes in the interdependent positions of individuals, but contradiction pervades these concepts. Although autonomy is seen in a positive light, following liberal understandings of personal freedom and control of the self, the state's "abandonment" of its responsibilities exposes the negative aspect of the term. In this latter sense people experience an undesired form of 
autonomy, which has been forcefully imposed on them. This abandonment is explicitly resented in relation to austerity cuts to health and education and to the blatant lack of protection of citizens deprived of housing through foreclosures.

Dependency on state subsidies is generally perceived as demeaning even when needed, but not all forms of dependence on the state are condemned. Universal social provisioning of public services such as health and education is not conceived as dependency but as a "right" attached to citizenship, and thus to political belonging. Finally, mutual help from voluntary association is understood as a positive form of dependency that contributes to asserting personal dignity, while charity help, on the contrary, is conceived as shameful and humiliating.

Solidarity also is variously described, often with overlapping meanings and affects attached. Generally speaking solidarity that is the result of individual "voluntary" association as in co-operatives, time banks, Local Exchange Trading Systems and other social economy entities is explicitly differentiated from "forced" solidarity. This later form of solidarity results from the replacement of state services with goods or services provided by charitable entities or with the help received from the family, described as "natural", despite the fact that kin support often produces extremely ambivalent and conflictive reactions (Thelen, 2015). Finally, yet another meaning of solidarity refers to collective mobilizations demanding changes in the present day political economic situation, focusing primarily on the demand for "food, jobs, housing and dignity" (Narotzky, 2016). For those older generations who were active in labor and anti-fascist struggles before the 1980s and who often remain the core of some of the newer mobilizations, solidarity is often 
understood as the making of an organized force of people in objectively similar structural positions, something they described as “the world of work" (rather than as a "class”) incorporating in this category a wide inventory of social positions (including petty entrepreneurs) as long as they have been “injured by capitalism” (Narotzky, 2015). In this part of the world, the tensions between the positive and negative aspects of dependence, autonomy and solidarity are based on the idealized equality and autonomy of a liberal enlightenment belief that everyday experience denies them in practice. People look for a job that will provide sufficient income to live with dignity, meaning by it, with a basic autonomy and, with it, the ability to voluntarily choose his or her (inter)dependent ${ }^{9}$ relationships (e.g. with family, interest groups, etc.). While dependency might be welcomed as a means of producing belonging and personhood, it is always premised on a romanticized position of individual "equality", leading to "freedom of choice”. This, for them, is what creates the conditions of possibility for "having a life", where mutual dependency becomes social inter-dependency, changing the value of dependency from negative to positive.

In this situation, practical consciousness expresses the material conditions and tensions in which people have to make a living. While, on the one hand, they aspire to retain enough autonomy to feel they have a "choice” (in the liberal sense) as manifest through income stability and consumption practices; on the other, they are forced to enter into various forms of dependency relations not of their own choice. In this conjuncture, solidarity seems to become for them a mediating ideology that can resolve the tension between the two. It becomes the method of struggle but also, often, its final objective. 


\section{Is a return to oppositional ideology possible? Is it desirable?}

In a recent conversation with one of my favourite interlocutors in the field, Ramon, an old time union leader who has been involved for the last 20 years in social activism outside the union, I was surprised by his strong attack on what he defined as “ideology”. In support of the new political party Podemos which decries the outmoded division between Left and Right, this former communist said: "We need to go beyond the ideological debate that has been co-opted by the old parties. The debate between Left and Right is an ideological debate, a symbolic debate, but interests go beyond ideology. We need to get to the grassroots, look into the problems that affect the people.” He described this need to go beyond "ideology" as a "tactical” movement that would produce a social force out of all those that were being injured by capitalism, a collective that he did not define as a “class” . This social force included small entrepreneurs suffering from the credit crunch, overtaxed self-employed workers, as well as unemployed people and mortgage holders suffering from foreclosures. Class in his view was a concept restricted to employed wage labour, and only made sense within strict trade union mobilizations.

For Ramon, the injuries of capitalism were closely connected to the new material conditions that neoliberal deregulation, financial capitalism and austerity cuts had brought about after the 2008 crisis. And the injuries of capitalism became something different from the injuries of class. Coming from someone that I have long admired as an exceptional political analyst, a socialist who had been trained in a pragmatic Marxist tradition I could not summarily dismiss this critique of ideology. What exactly did he mean by ideology? 
What was so negative about embracing an ideology? Could the term still hold a positive value as an instrument of class struggle? How can we struggle against hegemony without some kind of unified ideological framework?

In another conversation, a retired industrial worker, Juan, who is also now a social activist, reflected on the difficulties of collective mobilization in the present. He had been actively involved in a social movement—-the "Dignity Marches”- that emerged in 2014 in Spain in the wake of anti-austerity mobilizations primarily against public service cuts in the education and health systems (Narotzky, 2016). These marches were organized by civil society associations and some alternative unions and seemed to express a new kind of confluence of injured people. Most participants came from what could be defined as the lower echelons of a classic "working class” (mostly unemployed and precarious workers and their families). This “Dignity Marches” movement organized a march to Madrid (22 March 2014, 22-M) that brought approximately one million people from all over Spain claiming for "Pan, trabajo, techo y dignidad” (Bread, work, a roof and dignity). Juan's friend, Marcos, still employed and a committee member of the large Comisiones Obreras [CCOO] (Workers' Commissions) trade union in the local shipyard, countered that the Marches were a movement of the "lumpen", by which he meant people who are not "formed" who "do not possess a framing discourse that enables them to analyze the issues at stake”. He recognized nevertheless that the mobilizing initiative that used to be in the union's hands now was in the hands of “civil society.” The unions, he said, used to be an instrument for the articulation of struggle that had almost disappeared due to the cooptation of their leaders and to their lack of "ideological clarity” as they were tricked into 
thinking they were not “working class” but “middle class”. As he explained it, during the resistance to the Franco dictatorship, unions articulated a wider political and social class struggle that went far beyond trade issues; they were, then, the backbone of civil society instead of the self-centered interest group they now had become (Narotzky, 2014, 2015). Juan was dismayed because the impetus that mobilized people in the 22-M 2014 marches had disappeared. In September of 2015 I attended a small local meeting of the activists that organize the Marches where the objective of the movement was spelled out clearly: to unify different struggles. However, the practical results were virtually nonexistent: people did not respond to the organizers' calls to demonstrate in solidarity with other mobilizations. There were many small, targeted demonstrations everyday but no unifying solidarity across them. This small group saw their work as showing their support to all the different mobilizations -by being physically present-, and informing the participants about the unifying role of the "Marches". They stressed the need to "be in the street" and to "be encouraging" although in the meeting everyone saw the situation as pretty bleak. In order to think about the practice of contemporary collective struggle I will address the concept of solidarity which pervades the discourse of the people struggling to make a living and to respond to the injuries of capitalism. Is a theory of solidarity a new oppositional ideology? Solidarity is a concept that emerged in the $19^{\text {th }}$ century in France and had expanded into other areas of Europe and America by the end of the century. By the turn of the twentieth century three versions of the concept were fairly well established: labour solidarity (constructing class unity in order to confront the bourgeoisie), social solidarity (redistributing resources between and within generations through the state) and corporative 
solidarity (creating harmony among hierarchically differentiated social groups) (Blais, 2007). Many of the classical anthropological works (e.g. Durkheim, Mauss, and Malinowski) are directly or indirectly involved in this debate which I have addressed elsewhere (Narotzky, 2007).

In the historical debate the main questions addressed by proponents of all three perspectives were: determination vs. free will with regard to human action; society vs. the individual as the original component of humanity; equality vs. inequality in human relations and; the process that could configure the common good and therefore justice. These dialectical confrontations were part of often violent political struggles that claimed public legitimacy in terms of ideas about humanity, society, liberty, interdependence and a "higher good" to be accomplished in the future through political action. This debate was inscribed in the tension between Enlightenment and Modernity ideologies and Traditionalist and Catholic ones (Blais, 2007). I would argue that the issues that were at stake have not disappeared or even changed much, and reading Marx’s historical writings is very enlightening in this regard. Today, however, one of the theoretical positions in the debate has been able to incorporate its premises of singularity and exchange as a hegemony of form. Indeed, localized struggles against the uneven but connected expressions of capitalism appear as singular manifestations whose political value emerges in the global forum (the arena of exchange). The force of hegemony is in the form that mystifies real content.

If the debate about the ambiguous concept of solidarity has waned it is not because, now as before, people attribute different meanings to the concept, but because there is no intellectual effort to construct a theory where that concept in connection with others would 
provide a coherent model for social transformation. David Featherstone defines solidarity as a "relation forged through political struggle that seeks to challenge forms of oppression" (2012:5) Solidarities have also been described as "constructed through processes of relationality, connectivity and commonality between diverse place-based struggles” (Chatterton et al., 2013: 613). These understandings are based in the analysis of local struggles against particular expressions of capitalist oppression that connect with similar oppositional mobilizations across borders enabling the construction of trans-local "shared maps of grievances” across cultural and historical differences (Chatterton et al., 2013:614). However, analysts acknowledge the disabling long-term effect of different class positions, political allegiances, strategies and tactics that exists within the various groups that converge in concrete solidarity mobilizations. Admittedly, overcoming this would entail a broader political discussion (Borras, 2008, Chatterton et al., 2013) that would build an argument for the unification of struggles as a transformative project of the entire system. At the same time Andrea Muehlebach (2012) explores the connection between practices of solidarity and the neoliberal state, and highlights the ambiguous nature of the concept as it produces "moral neoliberal" subjectivities through "practices that are both oppositional and complicit at the same time” (2012:9)

But what kind of relation is "solidarity"? As a practice, solidarity is a coming together but the motives and objectives of this process can have multiple political implications. In particular the divergent meanings that emerged at the turn of the $20^{\text {th }}$ century are all still present: solidarity as (1) corporative togetherness (religious, ethnic, nationalistic manifestations of support), or as (2) autonomous liberal cooperation (such as volunteer 
mobilization in emergencies premised on universal Human Rights morality), or as (3) collective structural force (class-like organized struggles). In concrete social mobilizations several of these meanings may overlap or be transformed by internal tensions and historical meanings. But beyond its description of a practice, solidarity does not propose a coherent transformative project.

Solidarity, then, is not an oppositional ideology because it fails to connect to a coherent structure for change. The concept becomes a wide umbrella where many different projects may find shelter in the agora of their singular struggles, albeit for a short time. Still, the dominant meaning of solidarity in Western liberal democracies highlights individual autonomy and free will, which result in the emergent power of aggregate concrete projects. Neoliberal "globalization" stresses the force of an interconnected world that appears as the unified material expression of free-trade and of the benefits of the wide-world market discovery of universal tacit knowledge. Instead, as we have underlined above, counterhegemonic models rather than presenting a unified theory appear, unbeknownst, as an epistemological mirror of the Austrian school model where tacit knowledge is unveiled through exchange. Fundamentally, the unintentional and well-meaning extension to activist practice of a theoretical framing that adopts the form of the neoliberal market, i.e. an emergent process of discovery of what are to be considered as "goods" for the majority of people poses, I suggest, a serious political problem.

In his critique of Marxist political ideology, Lazaratto has pointed out that Marxism rests on an understanding of a wider totality where processes are connected to form a structure with a logic of movement. This belief orients the making of sense. It also enables the design 
of a "project", a stable alternative structure to aim at, creating the conditions of possibility for the transformation of the world in an oriented manner. On the contrary, the proposed "politics of the possible” rest on a perpetual assemblage of "exterior” relations (meaning not tied to a totality that structures sense), creating and enacting possible worlds. Singularity, multiplicity and the contingent creativity of the event that enables the emergence of "the possible" become the new tools for political mobilization (Lazaratto, 2006). This new (post-structuralist) epistemology explicitly eschews any model as a possible guide to political action and transformation. It opposes the idea that the world is a structured and meaningful articulation of connected ongoing relationships that can be stabilized through analysis and in theory, as a premise for acting upon it. Indeed the world may become structured only as a result of our will to make it comprehensible and malleable, so that we (humans) may act on in a particular way. How we give it form (structure) through practice and discourse both depends on, and defines how we can interact with it, and try to change it.

The problem of structure is, then, political. How to yield power and to what end. The possibility of defining a project as a pre-conception that designs a different structure (of connecting relationships) is alien to the new "philosophy of the event", which we have described above. Therefore, the meaning of politics can only emerge from the contingent connections that create possible worlds and simultaneously enact them. In this approach, political innovation and creativity emerge in a similar way to the Austrian school's conception in which the market -an arena of multitude singular events-helps unveil the knowledge that each individual creates in the spark of the exchange moment. This view, I 
suggest, expresses an epistemological and political ideology that mirrors the phenomenal form of capitalist relations. For the Austrian school, interference from a structured (i.e. planned) economic project (e.g. a social state project, cf. the socialist side of the socialist calculation debate) is anathema to the permanent discovery that the market enables. Likewise, interference from a political project (e.g. a conceived design of differently structured relationships) is anathema to the new politics of emergence. See for example the following quote: “The extraordinary energy of attraction and aggregation revealed by the $\mathrm{WSF}^{10}$ resides precisely in refusing the idea of a general theory. The diversity that finds a haven in it is free from the fear of being cannibalised by false universalisms or false single strategies propounded by any general theory. The time we live in, whose recent past was dominated by the idea of a general theory, is perhaps a time of transition that may be defined in the following way: we have no need of a general theory, but still need a general theory on the impossibility of a general theory." (Santos 2003b: 341, my emphasis)

\section{Conclusion: Waging the ideological war.}

Maybe I am pushing the analogy too far here. However, I suggest that this similarity in form is an expression of the consolidation of the neoliberal hegemony. Indeed it points to the difficulty of daring to conceive of and propose a coherent project of a different world that would provide tools to end the destruction, dispossession and devaluation of life that affects the great majority of people all over the world (as opposed to creating a mirage of myriad possible worlds waging partial and concrete struggles). Capitalism is a modern totalitarian reality that presents itself as the highest expression of individual freedom. The liberal ideology of creative interaction resulting from the unplanned decisions of individual 
unconnected wills in the market supports, in fact, a coherent and totalitarian project based on relations of depredation, dispossession and exploitation, sustained by regulated privilege and geared to capital and power accumulation in the hands of a few (humans).

Therefore a counter hegemonic force can only be created from a different formal framework, one that does not rest on the Austrian market model of creative discovery. I think we still need a unitary structure that can break down the hegemony of form that limits our present day struggles. We need an integrated theory that connects concrete, singular, struggles to a whole and might provide a structured understanding of the world we live in. While much of radical political economy scholars are repeatedly doing this in their analysis, the post-structural model dominates present-day oppositional politics. As I have addressed elsewhere (Narotzky, 2014) this results from histories of past betrayals and totalitarian enactments of grand theories, which make resentment and caution legitimate. We need, however, to overcome a handicap that we don't own. Different knowledges (or singularities) coming from different histories and cultural understandings need to be valued equally (equality) in their own terms (difference) but especially in terms of their potentiality to produce a structured, coherent, and powerful alternative that makes sense in a connected world. We are struggling against an enemy that has as its strongest weapon a hegemony that pervades our lives to the core in the West and increasingly all over the world. Admittedly, it is possible that the creative imagination of an alternative society will come from spaces not yet totally subsumed to capitalism that exist everywhere (Williams, 1977). But in order to accomplish durable change this vision needs to become an ideology of sorts where the many feel represented and willing to act. This 
ideology should be able to explain the experiences that most people have in their various forms of existence all over the world, and be able to propose an alternative that makes sense to the many all over the world. Indeed, in order to rehabilitate ideology as an oppositional instrument we need to pay attention to what people are doing and saying, and here the "sociology of absences" (Santos, 2003a) and the emphasis on "knowledges otherwise” (Escobar, 2007) is crucial to overcome the blindness that an hegemonic project has created. But we also need the courage to make connections and create logical paths, proposing a general theory of how social relations are governed and how they should be challenged and transformed.

I am referring here to what Eric Wolf defined as "structural power": "Structural power shapes the social field of action so as to render some kinds of behavior possible, while making others less possible or impossible.” (1990:587) At a level of signification we need to produce conceptual order, which will create a different mapping of what "sociologies" should be made "absent" (new "sociologies of absence"). We should be willing to draw a different selection of what connections count and what forms of knowledge we require in order to challenge the present structures of power. This, I suggest, is the ideology that we are at present unable to produce. At present, the only integrated alternative "oppositional" ideologies are being mostly provided by religions and nationalisms.

Ramon and Juan say they repudiate "ideology" as an instrument of struggle for "tactical" reasons. Left ideologies as entrenched in the discourses of governing parties (socialdemocratic parties) and classic trade unions are useless because they do not express the present-day injuries of capitalism. On the one hand, the ideology of the Left has been 
recurrently subverted and discredited by the actions of those who achieved power under that banner. On the other hand, the injured masses have changed and their real lives have subverted the classical Left labor/capital centered model of structural relations. While the classic wage relationship (lack of ownership of means of production and hence exploitation of labor) is still widely spread in most parts of the world, other forms of dispossession (e.g. financial rent extraction), dependency (petty commodity production, bonded labor) and abandonment (absolute surplus population) are growing. Therefore the old explanatory model does not make sense any longer in the present situation, and the attached transformative project has been repeatedly discredited by the parties’ practice. A return to the real world is necessary.

What Ramon and Juan see as a "tactical” move away from old models in order to better represent the experiences of the majority needs, however, to be reframed in a coherent framework that is able to challenge the logics of capitalism. The ethnographic position of listening to the variously injured voices and their practical proposals, does not exempt us from the responsibility to propose a different overall model of a better society and to believe that, at a particular historical conjuncture, the dominant model needs to be challenged by a unified force. This can only be achieved by the construction of a theory that relates the parts to a whole in a way that makes sense to the many and is capable of confronting the model of reality that is deeply entrenched in a hegemonic (Austrian market) form. To propose the need of such an integrated theory and its political expression as an oppositional ideology does not imply considering all struggles homogeneous; this would be unreasonable as we know that capitalism expresses itself unevenly. Neither does it imply 
that the theory or its constitutive elements (concepts, logical connections, analyses) will not be challenged; as the world changes they will and should be permanently put into question. But this is a war, and we need a powerful weapon that can match the neoliberal hegemony of form.

In the non-secular realms many models exist that directly (often violently) struggle for hegemony in different parts of the world. It is the secular realm (historically a product of the Enlightenment, and hence of the same liberal movement that supported the expansion of capitalism and socialism) that seems to be unable to produce an emancipatory model that subverts the neoliberal hegemony entrenched after the failure of the socialist experiments. Some models are incipient. One is the illiberal model of a hierarchical status society (an organic solidarity of the corporatist kind), which harmonizes difference by taming privilege through patronage and creating strong exclusionary borders and discarded people at the margins. This struggle to push oneself into the space of recognition by cultivating patronage networks (Ferguson, 2013) or by recurrently banning access to other claimants (Kalb, 2011; Holmes 2000) is very different from the one seeking to destroy enclosures on the basis that "another world is possible". In the latter category, the World Social Forum (WSF) model, which extends the liberal form to the struggles against capitalism, declines to produce a unified social project and supports a fragmented, partial and often inconsistent confrontation with the totalitarian forces of capital, a problem that is recognized by one of its more lucid advocates: "The other characteristic of transnational sub-politics, a negative one, is that, so far, theories of separation have prevailed over theories of union among the great variety of existing movements, campaigns and initiatives.” (Santos, 2001: 191). 
A model such as that of the WSF is commendable because it refuses to institute a dominant form of knowledge and the unique authority of a universal social model (Santos, 2003b: 341) in the face of a hegemonic model that normalizes oppression and exploitation. However, its strength is also its weakness. Instead, I propose that in order to transform the dominant political economic structure in such a way that capitalist forms of accumulation are destroyed and substituted by a human economy (Hart et al., 2010), it is necessary to have the courage of an oppositional ideology that can become a counter-hegemony benefiting the many.

\section{Acknowledgements}

The ICREA Academia Programme of the Generalitat de Catalunya provided a five-year fellowship that enabled me to dedicate more time to research (2010-2015). This article is based on research funded by the European Research Council Advanced Grant "Grassroots Economics: Meaning, Project and practice in the pursuit of livelihood" [GRECO], IDEASERC FP7, Project Number: 323743. I want to thank Nina Glick Schiller, Julia Eckert and Stephen Reyna for their comments on a first draft of this article. As always, this paper owes a lot to many conversations with Gavin Smith. I am solely responsible for its contents, however.

\section{Bibliography}

Blais MC (2007) La solidarité. Histoire d’une idée. Paris : Gallimard 
Borras SM Jr (2008) La Vía Campesina and its Global Campaign for Agrarian Reform. Journal of Agrarian Change 8(2-3): 258-289

Bourdieu P (2003) Méditations pascaliennes. Édition revue et corrigée. Paris: Seuil Collins J and Mayer V (2010) Both Hands Tied: Welfare Reform and the Race to the Bottom in the Low-Wage Labor Market. Chicago: The University of Chicago Press De Angelis M (2007) The Beginning of History: Value Struggles and Global Capital. London: Pluto Press.

Elyachar J (2012) Before (and After) Neoliberalism: Tacit Knowledge, Secrets of the Trade, and the Public Sector. Cultural Anthropology 27: 76-96

Escobar A (2007) Worlds and knowledges otherwise. Cultural Studies, Vol.21 (2): 179-210

Ferguson J (2013) Declarations of dependence: labour, personhood, and welfare in southern Africa. Journal of the Royal Anthropological Institute (N.S.) 19: 223-242

Featherstone D (2012) Solidarity: Hidden Histories and Geographies of Internationalism. London: Zed Books

Foucault M (2004) [1979] Naissance de la biopolitique. Paris : Gallimard-Seuil Gramsci A (1987) [1929-35]. Selections from the Prison Notebooks. New York: International Publishers.

Hart K, Laville JL and Cattani AD (eds) (2010) The Human Economy. Oxford: Polity Harvey D (2007) A Brief History of Neoliberalism. Oxford: Oxford University Press Hayek FA (ed) 1938. Collectivist Economic Planning. London: Routledge and Kegan Paul, Ltd. 
Hayek FA (1948) Individualism and Economic Order. Chicago: The University of Chicago Press

Holmes D (2000) Integral Europe. Fast-Capitalism, Multiculturalism, Neofascism.

Princeton: Princeton University Press

Holmes D (2009) Economy of Words. Cultural Anthropology Vol.24 (3): 38-419

Jacobs K and Manzi T (2013) New Localism, Old Retrenchment: The “Big Society”,

Housing Policy and the Politics of Welfare Reform. Housing, Theory and Society Vol. 30

(1): 29-45

Kalb D (2011) Headlines of Nation, Subtexts of Class: Working-Class Populism and the

Return of the Repressed in Neoliberal Europe. In: Kalb D and Halmai G (eds) Headlines of

Nation, Subtexts of Class. New York: Berghahn Books

Lange O (1936) On the Economic Theory of Socialism: Part One. The Review of Economic

Studies Vol. 4 (1): 53-71

Lange O (1937) On the Economic Theory of Socialism: Part Two. The Review of Economic

Studies Vol. 4 (2): 123-142

Lazaratto M (2006) Por una política menor. Acontecimiento y política en las sociedades de control. Madrid: Traficantes de Sueños

Li TM (2009) To Make Live or Let Die? Rural Dispossession and the Protection of Surplus Populations. Antipode 41(S1): 66-93

Lowndes V and Pratchett L (2012) Local Governance under the Coalition Government: Austerity, Localism and the 'Big Society'. Local Government Studies Vol.38 (1): 21-40 
Luxemburg R (1999) [1911] Mass Action. Marxist Internet Archives. Available at: http: //www.marxists.org/archive/luxemburg/1911/08/29.htm (accessed $1^{\text {st }}$ September 2012) Marx K (1859) 1977 A Contribution to the Critique of Political Economy.

Progress Publishers: Moscow. Marxist Internet Archives. Available at: https://www.marxists.org/archive/marx/works/1859/critique-pol-economy/preface.htm (accessed 19 March 2016)

Meyer H (2014) Reforming Social Democracy. The Good Society Project. Social Europe Occasional Paper. Available at: http://www.social-europe.eu/occasional-papers/op-4reforming-social-democracy-good-society-project/ (accessed 30 October 2014) Mitchell T (2002) Rule of Experts. Berkeley: University of California Press. Miyazaki H (2006) Economy of Dreams: Hope in Global Capitalism and Its Critiques. Cultural Anthropology. Vol.21 (2): 147-172

Muehlebach A (2012) The Moral Neoliberal. Welfare and Citizenship in Italy. Chicago: University of Chicago Press

Narotzky S (2007) The Project in the Model: Reciprocity, Social Capital and the Politics of Ethnographic Realism. Current Anthropology Vol.48 (3): 403-424

Narotzky S (2014) Structures without soul and immediate struggles: rethinking militant particularism in contemporary Spain. In: Kasmir S and Carbonella A (eds) Blood and Fire: Toward a New Anthropology of Labour. New York: Berghahn Books, pp. 167-202.

Narotzky S (2015) The organic intellectual and the production of class in Spain. In: Carrier JG and Kalb D (eds) Anthropologies of Class. Power, Practice and Inequality. Cambridge: Cambridge University Press, pp. 125-164 
Narotzky S (2016) Between inequality and injustice: dignity as a motive for mobilization during the crisis”. History and Anthropology. Vol.27 (1): 74-92

Narotzky S and Besnier N (2014) Crisis, Value, Hope: Rethinking the Economy. Current Anthropology Vol. 55 (S9): S4-S16

Negri A (2009) Insurgencies: Constituent Power and the Modern State (Theory Out Of Bounds). 2nd Revised edition. Minneapolis: University of Minnesota Press Perelman M (2000) The Invention of Capitalism: Classical Political Economy and the Secret History of Primitive Accumulation. Durham, NC: Duke University Press Pine F (2014) Migration as Hope: Space, Time, and Imagining the Future. Current Anthropology. Vol. 55 (S9): S95-S104

Pitrou A (2003) Conclusion: À la recherche des solidarités familiales. Concepts incertains et réalité mouvante. In : Debordeaux D and Strobel P (eds) Les solidarités familiales en question. Entraide et transmission. Paris: Droit et Société, Maison des Sciences de l'Homme

Polanyi K (1971) [1944)]. The Great Transformation. Boston: Beacon Press Polanyi M (1967) The Tacit Dimension. London: Routledge and Kegan Paul, Ltd. Santos BS (2004a) The World Social Forum : Toward a Counter-Hegemonic Globalisation (Part I). In: Sen J, Anand A, Escobar A and Waterman P (eds) World Social Forum: challenging empires. New Delhi: The Viveka Foundation Santos BS (2004b) The World Social Forum : Toward a Counter-Hegemonic Globalisation (Part II). In: Sen J, Anand A, Escobar A and Waterman P (eds) World Social Forum: challenging empires. New Delhi: The Viveka Foundation 
Smith G (2011) Selective Hegemony and Beyond—Populations with "No Productive Function”: A Framework for Enquiry. Identities: Global Studies in Culture and Power 18: 2-38

Thelen T (2015) Care as social organization: Creating, maintaining and dissolving significant relations. Anthropological Theory Vol.15(4): 497-515

Williams R (1977) Marxism and Literature. Oxford: Oxford University Press

Williams R (1989) Resources of Hope. London: Verso

Wolf E (1990) Distinguished Lecture: Facing Power - Old Insights, New Questions. American Anthropologist Vol. 92(3): 586-596

1 “In studying such transformations it is always necessary to distinguish between the material transformation of the economic conditions of production, which can be determined with the precision of natural science, and the legal, political, religious, artistic or philosophic -- in short, ideological forms in which men become conscious of this conflict and fight it out.” (Marx 1859).

2 “....it must be stressed that the political development of the concept of hegemony represents a great philosophical advance as well as a politico-practical one. For it necessarily supposes an intellectual unity and an ethic in conformity with a conception of reality that has gone beyond common sense and has become, if only within narrow limits, a critical conception.” (Gramsci 1987:333-4)

${ }^{3}$ The post-structuralist, ANT and ontological turns in anthropology have contributed a strong critique to this epistemological approach by variously pointing at (1) the variety of 39 
non-modernist forms of knowledge that have been silenced, (2) the complexity of subject status and (3) its post-human and changing being. I do not want to enter this theoretical debate.

${ }^{4}$ This perspective is completely different from the neoclassical one (in any of its forms) where knowledge is always already there and the problem is how to harmonize it through the operation of market interaction (e.g. the process of accessing information will create transactions costs, but information is presumed to pre-exist market interaction).

${ }^{5}$ I will not develop this analysis further, as it has been very clearly presented by others (Elson, 1988; Adaman \& Devine, 1997)

${ }^{6}$ Julia Elyachar (2012) has addressed the debate critically using her ethnographic material ${ }^{7}$ The fact that this is an hegemony means that those enacting it are presumably not aware of it.

${ }^{8}$ The distinction between different “worlds” and different "world-views” is critical to the ontological turn in anthropology.

${ }^{9}$ I use dependency to connote the power relations that are generally present in most human forms of cooperation and support. Inter-dependency refers instead to a relationship not infused with power based on sustained equality.

${ }^{10}$ World Social Forum 